\title{
Law-making Concretization of Basic Legislative Guidelines in the State Agrarian Policy of modern Russia
}

\author{
Yuliana Vadimovna Goryushina* \\ Tambov State University, Department of Theory and History of State and Law, Tambov, 392008, Russia
}

\begin{abstract}
The paper deals with scientific approaches to the definition of state agrarian policy and concretization in law. Through agrarian sphere, law-making decisions are analyzed, thus expanding and clarifying the subject of legislative regulation using the mechanism of law-making concretization. The author believes that law-making concretization of legal provisions is necessary because, once implemented, it ensures the quality and efficiency of the legal system. A formal legal, systemic method is used to trace vectors of legislative decisions taken in the agricultural sector, starting with the basic legislative directions and guidelines set forth by the state agrarian policy, which are detailed (concretized) by special laws and statutory laws.
\end{abstract}

\section{Introduction}

Lawmaking is a continuous, dynamic way of human activity outlining the features of social life, the rules and norms of mutual social behavior. The legislator first tends to consistently create a basic framework for regulating a particular sphere of relations, and subsequently, using various law-making mechanisms and techniques (concretization, amendments, itemization), regulatory legal provisions are detailed.

This (concretizing) process has a fundamental significance as it provides an opportunity for legislative bodies to highlight, regulate, supplement those areas of relations that currently call for greater political (governing) actions, rigorous surveillance, or, the other way around, to postpone, slow down certain areas that do not feel the need for coordination, oversight, or is not relevant.

Today, one of such areas requiring greater priority from the state and directly the legislator is the agricultural sector that provides the country with food, thereby supporting a crucial segment of national security (it is not fortuitous that Russia has adopted a special document - the Food Security Doctrine) [6]. In addition to this, the agricultural sector for the Russian Federation is its notable competitive advantage within the international division of labor, since it is Russian agrarian products that are in great demand on the world market due to quality, environmental safety, relatively low cost, etc., thus ensuring necessary volumes of export and greatly replenishing national budget.

\section{Results and discussion}

To help agriculture develop, the state implements (cannot fail to implement) a targeted agrarian policy aimed at the comprehensive and predictable development of national agriculture and rural areas.

The domestic literature contains various definitions of state agrarian policy. According to G.G. Fayzullin, state agrarian policy is one of the key elements constituting the state economic policy that bases the main lines of action for agricultural development. It is a set of measures taken by the state that provide extensive support for effective and competitive components of the national farming industry, aimed at observing constitutional rights of citizens in the agricultural sector and sustainable development of pastoral areas, as well as improving the quality of life of the rural population [21].

T.V. Abalakina and A.A. Abalakin define agrarian policy as an orderly activity of the state and public and legal institutions sanctioned by it to establish economic, social, legal and cultural living conditions of the rural population [15]. The definition is by far true, not indisputable, though. It is difficult to agree with this definition stating that the agrarian sphere is limited solely to the rural population, bearing in mind a modern feature of agricultural production being developed in close proximity to large industrial centers.

This conclusion is confirmed by the legislative definition of state agrarian policy, which is contained in the Federal Law On the Development of Agriculture that understands agricultural policy as an integral part of the state socio-economic policy aimed at sustainable development of agriculture and rural areas. Sustainable development of rural areas is viewed as their stable socio-economic development, increased volumes of 
agricultural production, greater efficiency of agriculture, full employment of the rural population and better standard of living, land management [1].

Besides, the legislator in the Federal Law On the Development of Agriculture defines the priorities in the state agrarian policy, which include:

1) steady provision of the population with Russian commodities;

2) establishment and regulation of agricultural products, commodities and food markets, development of infrastructure;

3) state support of farmers, as well as companies and individual entrepreneurs engaged in the primary and (or) subsequent (industrial) processing of agricultural products, scientific organizations, professional educational institutions, educational institutions of higher education, which in their research, scientific and technical and (or) educational activities engaged in agricultural production, primary and subsequent (industrial) processing in accordance with the list specified in Part 1 Article 3 of given Federal Law;

4) protection of economic interests of Russian agricultural producers in the domestic and foreign markets, promotion of their access to the markets of agricultural products, raw materials and food;

5) development of science and innovation in the farming industry;

6) sustainable development of pastoral areas;

7) improvement of the system of training and further professional education for agricultural personnel.

The following measures should be applied to ensure sound implementation of the state agricultural policy:

1) provision of budget funds to agricultural producers, scientific organizations, professional educational organizations, educational institutions of higher education, which, in their research, scientific and technical and (or) educational activities, are involved in agricultural production, primary and subsequent (industrial) processing;

2) application of special taxation schemes for agricultural producers;

3) procurement, storage, processing and supply of agricultural products, raw materials and food to meet state and municipal needs;

4) oversight of the market for agricultural products, raw materials and food, including customs, tariff and non-tariff regulation;

5) information support of agricultural producers and other participants in the market of agricultural products, raw materials and food, as well as providing them with counselling;

6) antitrust regulation of markets for agricultural products, raw materials and food;

7) participation of public organizations in crafting and implementing state agrarian policy;

8) procurement interventions, commodity interventions in the market of agricultural products, raw materials and food, as well as pledge transactions;

9) other measures provided for by the legislation of the Russian Federation.

According to the above guidelines, state support of the agricultural sector through various types of subsidies, benefits and grants has always been the cornerstone of Russian agricultural policy, like that of most economically developed countries.

However, almost all of the above can be referred to as the core provisions forming the backbone of agrarian legislation, indicating some basic vectors of activity that the state plans to implement so that agriculture develops at the required pace. Understandably, the main trend of the industry development is triggered not so much by these key provisions of the legislation, but by those specific legal prescriptions and dispositions that the legislator (the subject of lawmaking, the subject of lawmaking powers) takes on a permanent basis, detailing the source core legislative provisions. By this, such an important law-making function as law-making concretization is implemented (herewith, in the sphere of agrarian state-legal policy).

By adopting special subordinate laws that concretize, the legislator gives the general laws a chance to work more actively, to put into practice their ideological potential. However, more often legal concretization occurs at the level of secondary law-making. By concretizing legislative acts issued by the highest bodies of power, which have greater legal force, departmental (subordinate) normative acts detail them, relying on the originally pre-decided behavior contained in direct and reference legal norms of the highest legislative and executive bodies, being their follow-ups.

Formal concretization of law is the activity carried out by state and other authorized bodies to reduce the number of legal concepts by expanding their content, the results of which are put into certain legal acts [20]. This is necessary to ensure the quality and effectiveness of the legal regulation system. During the Soviet period, G.G. Shmeleva, one of the most prominent experts in domestic legal science, defined concretization of socialist laws as objectively conditioned, aimed at increasing the accuracy and certainty of legal regulation, natural activity of state and other authorized bodies to transfer the abstract content of legal norms to a more specific level by limiting concepts, the results of which are put into legal acts [22].

Concretization, resulting in legal definitions to give certainty to legal phenomena and concepts, is mentioned by N.A. Vlasenko [16]. The researchers also turn to the importance of legislative concretization as a "programmed" fragmentation enabling to prevent unwarranted expansion of the subject of legislative regulation and relations it covers regulated by by-laws, thus respecting hierarchical, competence, and substantive limits [17].

One of the features of legislative concretization is its multi-stage character underpinning that the broadest possible rule is transformed when applied to certain objects, subjects or situations, being reflected in a law or by-law of the same or lower legal force [19].

Let us try to keep track of the development and specifics of the law-making concretization applied to the core guidelines of the lawmaker through the example of agricultural legislation, which is a necessary state stage of agricultural policy. 
In 2012, with a view to implementing the basic federal law On the Development of Agriculture, the Government of the Russian Federation approved the State Program for Agricultural Development and Regulation of Agricultural Products, Commodities and Food Markets [8], whose actual timeline included a program stage, completed in 2013-2017, and a project stage to be implemented from 2018 to 2025 [10].

In 2018, the President of the Russian Federation defined national goals and strategic objectives for the development of the Russian Federation, which are being implemented today within a number of national projects (programs) [5]. In the field of agriculture:

- Digital Economy of the Russian Federation provides for the transformation of priority sectors of the economy and social sphere, including agriculture;

- a national program in the field of culture envisages the establishment (reconstruction) of cultural and leisure centers in rural settlements, the development of municipal libraries;

- a national project to promote small and mediumsized businesses and support for individual entrepreneurial initiative involves the establishment of a system of support for farmers and the development of rural cooperation;

- a national program to foster international cooperation and export provides for the achievement of the following goals and targets: the establishment of global competitive non-resource sectors in agriculture, with a total share of exported goods (works, services) to be at least 20 percent of the national gross domestic product.

It is also important to note that the state agrarian policy is closely interacting with the state socioeconomic policy to ensure the food security of the Russian Federation [3, 6].

Global processes, including political events, have undoubtedly affected further development of agrarian policy. The planned arrangements mediated the development of a set of measures that can affect several sectors of the economy at once.

Thus, in order to protect national interests of the Russian Federation, a ban (restriction) was introduced on foreign economic transactions that provide for certain types of agricultural products, raw materials and foods being imported from a country that decided to impose economic sanctions against Russian legal entities and/or individuals or that acceded to this decision [4].

The emphasis placed by the legislator were fixed in special laws, federal regulations of the Russian Federation.

Pursuant to a special anti-sanction decree of the President of the Russian Federation, resolutions of the Government of the Russian Federation concretize a list of countries producing agricultural products, in respect of which a ban is introduced on the import of raw materials and foodstuffs into the Russian Federation, including Australia, Canada, EU countries, Kingdom of Norway, Montenegro, the Principality of Liechtenstein, Republic of Albania, Republic of Iceland, Ukraine, and United States of America) [9,11].
A food embargo imposed on the above countries in 2014 marked the beginning of the implementation of the import substitution program laid back as far back as 2009.

Thus, Decree No. 1544 of the Government of the Russian Federation dated December 13, 2017 amended the State Program for Agricultural Development and Regulation of Agricultural Products, Commodities and Food Markets, suggesting the development of some agrarian branches accelerating import substitution of main types of agricultural products, raw materials and food as one of the priorities of the State Program (subprogram) [12].

The state agrarian policy is implemented by the Ministry of Agriculture of the Russian Federation [7], public authorities in the constituent entities of the Russian Federation, unions (associations) of farmers that produce more than two-thirds of the total production of certain types of agricultural products, raw materials and food and provide related services. Meanwhile, one of the forms of participation of unions (associations) of agricultural producers in the crafting and implementation of state agrarian policy is the development of draft regulatory legal acts, target programs, a national report [1].

I.V. Mikheeva mentions that it is a tradition for Russian ministries to concretize, supplement, and detail basic laws as types of subordinate law-making [18].

\section{Conclusion}

The powers of federal ministries to participate in public law-making policy are enshrined in Clause 3 of Decree No. 314 of the President of the Russian Federation On the System and Structure of Federal Executive Bodies, dated March 09, 2004 [2]. It says that federal ministry is a federal executive body performing functions on the development of state policy and legal regulation in that activity established by acts of the President of the Russian Federation and the Government of the Russian Federation.

As far as the Ministry of Agriculture of the Russian Federation is concerned, Regulation No. 450 on the Ministry of Agriculture of the Russian Federation, approved by the Government of the Russian Federation dated June 12, 2008 lays down the detailed functions of developing and implementing state policy and legal regulation [7].

As part of the said issue, the Ministry of Agriculture of Russia developed and adopted numerous concretizing regulatory legal acts, including those stipulating methods for calculating the value of a number of indicators under the State Program for Agricultural Development and Regulation of Agricultural Products, Commodities and Food Markets [13, 14].

By detailing normative legal acts of the Russian parliament, the Ministry of Agriculture of the Russian Federation, in turn, expresses the function of developing rulemaking, which is inherent in the respective agents of lawmaking. This function of lawmaking in the context of dynamically developing social relations is extremely 
important, which is particularly obvious in agrarian legislation that incorporates basic (relatively stable) principles and dynamically concretizing legislative prescriptions, the quality requirements of which are in no way diminished by their detailed character in relation to the basic laws, but only increase in practice.

Law-making techniques are properly applied through the mechanism of concretization of legal norms, thus contributing to the quality and efficiency of the regulatory framework. This is particularly evident in the implementation of modern state agrarian policy.

\section{References}

1. Federal Law No. 264-FZ On the Development of Agriculture dated December 29, 2006. Collected Legislation of the Russian Federation. No. 1 (Part I). Article 27 (2007)

2. Decree No. 314 of the President of the Russian Federation of March 09, 2004 On the System and Structure of Federal Executive Bodies. Rossiyskaya Gazeta, No. 50 (March 12, 2004)

3. Decree No. 120 of the President of the Russian Federation of January 30, 2010. Collected Legislation of the Russian Federation. No. 5. Article 502 (2010)

4. Decree No. 560 of the President of the Russian Federation dated August 06, 2014 On the Application of Certain Special Economic Measures to Ensure the Security of the Russian Federation. Collected Legislation of the Russian Federation. No. 32. Article 4470 (2014)

5. Decree No. 204 of the President of the Russian Federation of May 07, 2018 On National Goals and Strategic Objectives of the Development of the Russian Federation for the Period up to 2024. Collected Legislation of the Russian Federation. No. 20. Article 2817 (2018)

6. Decree No. 20 of the President of the Russian Federation dated January 21, 2020 On the Approval of the Food Security Doctrine of the Russian Federation. Collected Legislation of the Russian Federation. No. 4. Article 345 (2020)

7. Resolution No. 450 of the Government of the Russian Federation of June 12, 2008 On the Ministry of Agriculture of the Russian Federation. Collected Legislation of the Russian Federation. No. 25. Article 2983 (2008)

8. Resolution No. 717 of the Government of the Russian Federation of July 14, 2012 On the State Program for Agricultural Development and Regulation of Agricultural Products, Commodities and Food Markets. Collected Legislation of the Russian Federation. No. 32. Article 4549 (2012)

9. Resolution No. 778 of the Government of the Russian Federation dated August 07, 2014 On Measures to Implement Decrees of the President of the Russian Federation No. 560 dated August 06, 2014, No. 320 dated June 24, 2015, No. 305 dated
June 29, 2016, No. 293 dated June 30, 2017, No. 420 dated July 12, 2018, No. 293 dated June 24, 2019 and No. 730 dated November 21, 2020. Collected Legislation of the Russian Federation. No. 32. Article 4543 (2014)

10. Resolution No. 98 of the Government of the Russian Federation of February 08, 2019 On Amendments to Decree No. 717 of the Government of the Russian Federation of July 14, 2012. Collected Legislation of the Russian Federation. No. 7 (Part I, II). Article 631 (2019).

11. Resolution No. 2054 of the Government of the Russian Federation dated December 09, 2020 On Amendments to Decrees of the Government of the Russian Federation No. 778 dated August 07, 2014 and No. 774 dated July 31, 2015. Collected Legislation of the Russian Federation. No. 51. Article 8443 (2020).

12. Resolution No. 1544 of the Government of the Russian Federation of December 13, 2017 On Amendments to the State Program for Agricultural Development and Regulation of Agricultural Products, Commodities and Food Markets for 2013 - 2020. Collected Legislation of the Russian Federation. No. 52 (Part I). Article 8126 (2017)

13. Order No. 444 of the Ministry of Agriculture of Russia dated July 01, 2021 On Approval of the Method for Calculating the Indicator "Volume of Wheat Production of the First-Third Classes" within the departmental project Development of Branches of the Farming Industry Accelerating Import Substitution of Basic Agricultural Products, Raw Materials and Food under the State Program for Agricultural Development and Regulation of Agricultural Products, Commodities and Food Markets, approved by decree No. 717 of the Government of the Russian Federation of July 14, 2012 (The text of the order was not published)

14. Order No. 538 of the Ministry of Agriculture of the Russian Federation dated October 09, 2020 On Approval of the Method for Calculating the Indicator "Gain in the Production of Open Field Vegetables in Agricultural Organizations, Peasant (Farmer) Households, Including Individual Entrepreneurs, for the Reporting Year against the Indicator Provided for by the Agreement with the Subject of the Russian Federation, for the Previous Year" within the departmental project Development of Branches of the Farming Industry Accelerating Import Substitution of Basic Agricultural Products, Raw Materials and Food under the State Program for Agricultural Development and Regulation of Agricultural Products, Commodities and Food Markets (The text of the order was not published)

15. T.V. Abalakina, A.A. Abalakin, State agrarian policy as an integral part of the general economic policy of the Russian Federation, Fundamental and applied research of the cooperative sector of the economy, 3, 49-53 (2008) 
16. N.A. Vlasenko, Judicial legal definitions: nature, functions, division grounds and types, Journal of Russian Law, 12(156), 58-67 (2009)

17. M.V. Zaloilo, Fragmentation as a modern trend in the development of legal space, Law. Journal of the Higher School of Economics, 1, 27-49 (2020)

18. I.V. Mikheeva, Russian lawmaking: traditional aspects of history, Journal of Russian Law, 10(166), 98-105 (2010)

19. S.V. Polenina, Constitutional problems of lawmaking, in: Russian constitutionalism: problems and solutions. Proceedings of the International Conference (ISL RAS, Moscow, 1999) pp. 151-155.
20. P.M. Rabinovich, G.G. Shmeleva, Concretization of legal norms (general theoretical problems), News of higher educational institutions. Law studies, 6, 31-39 (1985)

21. G.G. Fayzullin, Agrarian policy as the most important direction of the domestic policy of the Russian Federation, Agrarian and Land Law, 9(33), 19-27 (2007)

22. G.G. Shmeleva, Concretization of legal norms in legal regulation (Vyscha Shkola, LSU Publishing House, Lvov, 1988) 104 p. 